\title{
Educação Sexual - quando a articulação de múltiplos discursos possibilita sua inclusão curricular
}

\author{
Jimena Furlani*
}

\section{Resumo:}

Hoje, no contexto da escolarização brasileira, é possível encontrar espaço no currículo para a Educação Sexual? Em que medida a sociedade contemporânea criou (e cria) demandas que favorecem a inclusão curricular de temáticas como a sexualidade, o gênero, as políticas identitárias? O que este contexto histórico e essa demanda têm a dizer aos cursos de formação de educadores(as)? Defendo o pressuposto de que a última metade do século $\mathrm{XX}$ foi determinante na discussão e na inclusão da Educação Sexual nos âmbitos social e educacional, no Brasil. Segundo Michel Foucault, múltiplos discursos participam na construção dos saberes sociais acerca das sexualidades e dos gêneros. Esses discursos se articulam por "descontinuidades históricas" nos processos que definem as representações acerca dos sujeitos e de suas identidades culturais. Apresento um mapeamento histórico de demandas de ordem política, cultural, midiática, pedagógica, estética e econômica que parecem apontar para as possibilidades temáticas e didáticometodológicas que um currículo da Educação Sexual pode assumir nos dias de hoje, em qualquer nível do ensino.

Palavras-chave: Educação Sexual Educadores - Formação.

\footnotetext{
* Doutora em Educação pela Universidade Federal do Rio Grande do Sul. Professora da UDESC - Universidade do Estado de Santa Catarina, no Centro de Ciências Humanas e da Educação, no Curso de Pedagogia.
} 


\section{Introdução}

Principalmente durante as últimas cinco décadas do século $\mathrm{XX}$, inúmeros acontecimentos promoveram uma maior visibilidade de questões $^{1}$ relacionadas aos gêneros e às sexualidades, em especial no Ocidente. Diversos movimentos sociais (sexuais, raciais, étnicos, ecológicos, religiosos, de gênero, de nacionalidade), ao buscarem afirmar a própria voz, contribuiram (e contribuem) para evidenciar a existência de distintas políticas de identidade no campo da cultura. Política de identidade se refere ao "[...] conjunto de atividades políticas centradas em torno da reivindicação de reconhecimento da identidade de grupos considerados subordinados relativamente às identidades hegemônicas" (SILVA, 2000, p. 92). Quer seja por pressão da opinião pública (especialmente, em decorrência da "pressão" desses movimentos), quer seja pela iniciativa de educadores(as) e dirigentes escolares, os efeitos desses movimentos identitários parecem estar refletindo nos currículos escolares e nas últimas políticas públicas de educação.

A reformulação curricular da Educação Básica brasileira, por exemplo, ocorrida com a aprovação da LDB - Lei 9.394/96, apontou para alguns desses ecos. Com ela, a política governamental lançou, a partir do ano de 1997, os Parâmetros Curriculares Nacionais (PCNs), que, além de reestruturarem as disciplinas dos Ensinos Fundamental e Médio, sugeriram Temas Transversais como campos disciplinares a serem perpassados em todas as séries, não como disciplinas, mas como assuntos necessários à formação de cidadãos e cidadãs. Além de ética, saúde, pluralidade cultural, meio ambiente e estudos econômicos, pela primeira vez, de modo explícito, a sexualidade e as relações de gênero têm espaço no então chamado tema transversal "orientação sexual". ${ }^{2}$ Os PCNs possibilitaram um contexto educacional favorável a essa inclusão temática.

No entanto, parece ser possível, ainda, argumentar acerca de um favorável "panorama" histórico que, segundo o entendimento de Foucault (2000), aponta para a "convergência de múltiplos discursos" no processo social de atribuição de significados e construção das identidades sexuais e de gênero. A "identidade" aqui referida é identidade cultural, e não possíveis noções de "identidade" segundo teorizações dos campos da Psicologia. Segundo Silva (2000, p. 69), “[...] de acordo com a teorização pós-estruturalista que fundamenta boa parte dos Estudos Culturais 
contemporâneos, a identidade cultural só pode ser compreendida em sua conexão com a produção da diferença, concebida como um processo discursivo". Sexo, gênero, sexualidade, raça, etnia, religião, nacionalidade, geração, classe social são exemplos de identidades culturais. ${ }^{3}$

Para Foucault (2000, p. 146) "[...] o discurso não tem apenas um sentido ou uma verdade, mas uma história [...]”, e os enunciados que constituem um discurso se articulam por meio de descontinuidades históricas. Neste entendimento, não me interessa a apropriação da história como se ela fosse algo linear (com sucessões de épocas ou séculos) e, por si só, explicativa de uma causalidade dos fatos. No relato histórico que pretendo apresentar, procurarei distanciar-me da postura factual, evolutiva, progressista com que os fatos históricos geralmente são apropriados. Para chegar aos processos sociais que hoje constroem os discursos presentes na Educação Sexual, pretendo reforçar o entendimento das descontinuidades históricas, ou seja, da importância dos "fenômenos de rupturas" (FOUCAULT, 2000, p. 4). O emprego dos conceitos de descontinuidade, de ruptura, de limiar, de limite, de série, de transformação coloca, a qualquer análise histórica, não somente questões de procedimento, mas também problemas teóricos (FOUCAULT, 2000, p. 23).

Segundo Carvalho (2001), ao enfatizar o entendimento da ruptura, Foucault refuta qualquer perspectiva de progresso nos estudos de produção do saber.

Essa posição, além de apontar para a impossibilidade da busca de origens remotas ou de "precursores" como já haviam feito Bachelard (1977, 1996), Canguilhem (1968) e Koyré (1966) -, coloca totalmente em xeque a idéia de evolução da verdade segundo um tempo ordenado. A concepção de progresso deixa de ser um a priori. A passagem de um registro de saber a outro, marcada pela descontinuidade, não assegura ou permite falar em evolução. Por mais que sejam semelhantes, os objetos jamais serão os mesmos, assim como as maneiras de olhá-los (o que se reflete principalmente ao nivel conceitual), as formas de enunciação e de organização dos pensamentos (CARVALHO, 2001, p. 122). 
Os eventos históricos que serão apresentados foram reunidos e buscados, intencionalmente, como "acontecimentos dispersos" (FOUCAULT, 2000, p. 24). Embora neste artigo estejam, didaticamente, organizados numa proximidade cronológica, não devem ser vistos como caracterizadores de um determinismo histórico e gradual dos saberes sobre as sexualidades e os gêneros, da mesma forma que nenhum evento gozará do status de ser "o fato único gerador da história". Entendo que todos foram (e são) acontecimentos sociais, tornados (ou não) "fato histórico" num processo de construção humana. Podem ter sido antecedidos e/ou sucedidos por outros eventos, articulados (ou não) entre si, complexos e mutuamente atuantes, divergentes e/ou convergentes. Foram (e são) essas várias e múltiplas condições históricas que permitiram, a distintos acontecimentos, se associarem, se conjugarem e se articularem de algum modo. Em contextos específicos e por serem constituintes de uma mesma formação discursiva, possibilitaram/possibilitam a emergência de discursos sobre os gêneros e as sexualidades (reiterando o caráter discursivamente construído de ambos).

Fischer (2003), no artigo "Foucault revoluciona a pesquisa em Educação?", referiu-se à análise do discurso como uma análise enunciativa foucaultiana. Afirmou que

[...] descrever enunciados [...] significa apreender as coisas ditas como acontecimentos, como algo que irrompe num tempo e espaço muito específicos, ou seja, no interior de certa formação discursiva - esse feixe complexo de relações que "faz" com que certas coisas possam ser ditas (e serem recebidas como verdadeiras), num certo momento e lugar. (FISCHER, 2003, p. 374).

Pretendo que essa retomada histórica favoreça o olhar problematizador sobre a sociedade contemporânea, sobre as pedagogias das sexualidades e dos gêneros, sobre a Educação Sexual. Entendo que as muitas representações contidas nas várias formações discursivas definem, hoje, "o que pode ser dito" sobre essa temática e estão presentes ou perpassam os currículos escolares, os livros didáticos e paradidáticos, os sujeitos escolares - aspectos esses que parecem, cada vez mais, imprescindíveis em qualquer processo de formação de educadoras(es). 


\section{Educação Sexual - um campo constituído por múltiplos dis- cursos}

No Brasil, em 1997, com o lançamento dos PCNs, o Estado determinou uma política educacional, instituindo a discussão de aspectos ligados à Educação Sexual no sistema formal de ensino, nos âmbitos federal, estadual e municipal. É possivel afirmar, contudo, que esta discussão nunca esteve completamente ausente da escola, especialmente se pensarmos na sexualidade como uma dimensão constituinte e presente no desenvolvimento humano, em qualquer fase da vida (mesmo que "negada", sobretudo em relação à criança). ${ }^{4}$

A Educação Sexual sempre se constituiu numa questão polêmica no espaço escolar, e por largo tempo os currículos escolares mantiveramse distantes dessa discussão explicitamente. Por isso, é possível pensar nela como um campo de conhecimento em que, historicamente, tem prevalecido o conveniente silenciamento, a estratégica restrição temática, o privilegiamento do senso comum, a manutenção do preconceito e da intolerância, a possível falta de preparo pedagógico das(os) educadoras(es) e o sutil descaso por parte da Escola e das políticas educacionais.

Se pensarmos a questão com o apoio no ponto de vista foucaultiano, poderíamos remontar nossa análise, por exemplo, aos primeiros tempos do capitalismo. Para este Foucault (1993, p. 11), "Se o sexo é reprimido com tanto rigor, é por ser incompatível com uma colocação no trabalho, geral e intensa". Para Foucault (1993, p. 11), referindo-se ironicamente aos efeitos do sistema capitalista, a função social do sexo só seria tolerada numa "[...] época em que se explora sistematicamente a força de trabalho", e os prazeres tolerados deveriam convergir apenas para o objetivo da reprodução. Essa compreensão ajudou a desenvolver a idéia de que a sexualidade se constituía, antes de tudo, num problema a ser entendido, contido, regulado e classificado.

A segunda metade do século XIX foi profícua em estudos e publicações sobre a sexualidade humana, especialmente na Europa, com o surgimento dos "primeiros demógrafos e psiquiatras" (FOUCAULT, 1993 , p. 12), que favoreceram o desenvolvimento, mais enfaticamente, de uma representação de normalidade indissociada da heterossexualidade, do casamento, do controle populacional e da reprodução, e vinculada à admissão de uma vida sexual eminentemente adulta. 
As preocupaçães mundiais com o aumento da população e, em conseqüência, com a criação de tecnologias da sexualidade a fim de controlar seus corpos e suas vidas, segundo Weeks (2000, p. 53), já estavam presentes nos anos 1940: "[...] período crucial para o estabelecimento do estado de bem-estar em muitas sociedades ocidentais". Além das preocupações com o planejamento familiar e o número de filhos, definiam-se também "[...] os papéis apropriados para os homens e mulheres (especialmente mulheres) na familia, no admirável mundo novo da democracia social" (WEEKS, 2000, p. 53).

Talvez possamos pensar que, ao discurso demográfico que emergiu em meados do século XIX, e pertencente à emergência de uma biopolítica (sobretudo, do controle populacional), hoje se somam outras questões. Preocupações decorrentes do surgimento do HIV, na década de 1980, e da problemática da gravidez na adolescência, em especial no Terceiro Mundo, em países latino-americanos, têm estado na base para a justificativa de alguns programas de Educação Sexual institucionalizados. Por exemplo: já na década de 1970, organismos e instituições internacionais promotoras do controle da natalidade e da contenção de proliferação de DSTs foram fortemente influenciados por um documento chamado Relatório Kissinger (NSSM 200). ${ }^{5}$ Esse documento, intitulado "Implicações do crescimento da população mundial para a segurança e os interesses internacionais dos Estados Unidos", norteou a determinação e o investimento em projetos de Educação Sexual pelo mundo e, no Brasil, justificou alocar recursos em projetos definidos como "de população" registrados no documento "Inventário dos projetos de população ao redor do mundo", do Fundo de População da ONU. Os textos a seguir explicitam parte do entendimento de ação desse relatório:

Muito pouca atenção é dada à educação sobre população ou sobre Educação Sexual nas escolas e, em muitos países, nada é ensinado mesmo nos níveis iniciais em que apenas $2 / 3$ ou $3 / 4$ das crianças são atendidas. (RELATÓRIO..., 1974, p. 157, grifo meu).

Concentração nos países-chaves. a assistência para o controle populacional deve ser empregada principalmente nos paises em desenvolvimento de maior e mais rápido crescimento onde os EUA têm interesses politicos e estratégicos especiais. Esses países são Índia, 
Bangladesh, Paquistão, Nigéria, México, Indonésia, Brasil, Filipinas, Tailândia, Egito, Turquia, Etiópia e Colômbia. (RELATÓRIO..., 1974, p. 14-15, grifos meus).

Programas práticos e simplificados de educaf̧ão devem [...] incluir curriculos especificos que motivem a próxima geração a desejar familias de dois filhor, a fim de assegurar esse nivel de fertilidade em duas ou três décadas [...] e introduzir o planejamento familiar no curriculo. (RELATÓRIO..., 1974, p. 144, grifos meus).

Neste período, no Brasil, houve outras iniciativas a uma Educação Sexual visando à contracepção, em primeiro plano. Destacam-se:

- a publicação de sete folhetos/cartilhas, pelo Ministério da Saúde, impressos pelo Programa de Assistência Integral à Saúde da Mulher e da Criança, patrocinado pela Fundação Ford, Fundação Carlos Chagas e pelo The Pathfinder Fund. As cartilhas foram elaboradas por grupos feministas com a participação de Maria Helena Matarazzo, Marta Suplicy, Maria José Lima e várias outras;

- posteriormente, foi publicado o livro Saúde sexuale reprodutiva: ensinando a ensinar, destinado a preparar professoras(es) de Educação Sexual. Esse trabalho, financiado também pelo The Pathfinder Fund, foi executado pelo CESEX (Centro de Sexologia de Brasília), cumprindo uma das cláusulas do Termo de Cooperação Técnica e Financeira celebrado entre o CESEX, a Fundação Emílio Odebrecht (FEO) e os Ministério da Saúde e da Educação. Segundo o documento, em sua apresentação, competia ao CESEX, entre outras atribuições, elaborar um material instrucional a ser usado em todo o território brasileiro na formação de educadores e multiplicadores na área da Saúde Sexual e Reprodutiva. Para esta tarefa, seria muito proveitoso convidar também a equipe do Centro de Pesquisas e Controle das Doenças Materno-Infantis de Campinas (CEMICAMP). (RENATO, 1996). 
Segundo o Relatório Kissinger, havia países em que o índice populacional apresentaria crescimento projetado para década de 1970, quando o auxílio financeiro dos EUA encontrava resistência. Essa oposição se dava, quer por causa da natureza das relações políticas ou diplomáticas com esses países (como na Índia e Egito), quer por causa da falta de interesse governamental nos programas de redução da população (como na Nigéria, na Etiópia, no México e no Brasil). Em tais casos, a assistência técnica e financeira externa teria de vir de outros doadores e/ou de organizações internacionais e privadas.

Neste contexto, surgiu a Sociedade Civil do Bem-Estar Familiar no Brasil (BENFAM), fundada no Rio de Janeiro em 1965, hoje atuando em quatorze Estados brasileiros. Ela define-se como “[...] organização nãogovernamental, de ação social, pioneira na defesa dos direitos de homens, mulheres e adolescentes à assistência em saúde reprodutiva e à decisão livre e informada sobre planejamento familiar". 6 Embora, atualmente, incorpore as preocupações com os direitos de homens e adolescentes, a BENFAM originou-se numa época em que os programas apresentavam nítido atravessamento de gênero, ou seja, quando a mulher se constituía o centro do investimento pelo controle populacional. Em relação a isso, o Relatório Kissinger (1974) expressa o discurso dominante, que colocava a mulher numa inquestionável centralidade nas ações de controle da população. $O$ alcance de seus objetivos excluía a participação do homem no planejamento familiar e nos projetos governamentais voltados à saúde sexual (como atesta a criação, no Brasil, do Programa de Assistência Integral à Saúde da Mulher e o Programa de Assistência Materno-Infantil).

Parece que, no discurso médico e nas políticas públicas de saúde, por muito tempo, os homens estiveram no papel secundário. Entretanto, o final dos anos 1990 já mostrava que uma nova demanda de gênero ressignificaria as representações no contexto das masculinidades: aparecem nos projetos sociais, mesmo que timidamente, assuntos e temáticas que ocupam mais visivelmente a mídia, os consultórios médicos e as conversas informais de finais de semana, como sexo seguro, controle reprodutivo, infertilidade, disfunção erétil, impotência, saúde sexual, câncer de próstata, andropausa. $^{7}$

Arrisco dizer que, em meados do século XX, os significados enunciativos, presentes nas políticas públicas de saúde, apontavam para um 
encaminhamento, aparentemente, contraditório. Por um lado, defendiam a igualdade social da mulher em relação ao homem; constantemente, recomendavam a inclusão das mulheres na participação política, no mercado de trabalho, nas políticas salariais, na educação. Por outro lado, esta estimulada "emancipação" feminina parecia que apontava para a utilização ideológica de uma representação de mulher atrelada ao controle dos nascimentos - considerados indesejáveis e perigosos aos "interesses mundiais":

A condição e a utilização das mulheres nas sociedades dos países subdesenvolvidos são particularmente importantes na redução do tamanho da familia. [...] As pesquisas mostram que a redução da fertilidade está relacionada com o trabalbo da mulher fora do lar. (RELATÓRIO..., 1974, p. 151, grifo meu).

Para que o Plano Mundial de População fosse eficiente, era preciso, entre outras ações, que o discurso hegemônico fosse capaz de levar ao declínio da fertilidade, incentivando as pessoas a terem familias menos numerosas. Como estratégias de ação, o Relatório Kissinger assim sugeriu em seu texto: que os países "[...] aumentem as oportunidades de trabalho, principalmente para as mulheres [...] e eduquem as novas gerações a desejarem familias menos numerosas" (RELATÓRIO..., 1974, p. 16-17). Ao final e reiterando a determinação, enfatiza, em "Algumas recomendações mais importantes", no item 12, que "Os governos devem assegurar a total participação das mulheres na vida educacional, econômica, social, e política de seus países em igualdade de condições com os homens" (RELATÓRIO..., 1974, p. 90-93).

Como uma poderosa "tecnologia de governo" (FOUCAULT, 1993), a educação adquiriu centralidade nas estratégias de controle populacional, nos discursos sobre desenvolvimento, também presentes nas políticas públicas das décadas de 1960 e 1970 . Em alguns momentos, o discurso hegemônico foi emblemático neste sentido. $\mathrm{Na}$ ênfase concedida à educação, nas "recomendações mais importantes", é possível encontrar pontos tacitamente contraditótios: os itens 4 e 5 recomendavam aos países incentivar uma educação que levasse à paternidade responsável, dando informações e meios para que as pessoas tivessem os filhos que desejassem (a escolha no número de filhos deveria ser individual e livre). Para isso, a 
meta do planejamento familiar deveria ser impedir as gravidezes indesejadas e eliminar a esterilidade ou a subfecundidade involuntárias. Entretanto, dirá também que há ações que parecem conter a redução da fertilidade. Portanto, os países deveriam "[...] ter como prioridade educar e ensinar sistematicamente a próxima geração a desejar famílias menos numerosas" (RELATÓRIO..., 1974, p. 111).

A Educação Sexual adquiriu papel fundamental neste contexto histórico de controle populacional. Ela deveria discorrer:

[...] sobre os eficientes meios de reduqir a mortalidade infantil; sobre os métodos para integrar as metas populacionais aos planos nacionais; sobre os métodos de controle da fertilidade, inclusive métodos que não exijam supervisão médica; sobre as inter-relações da saúde, nutrição e biologia reprodutiva, sobre os métodos para melhorar a utilização e distribuição dos serviços sociais, inclusive os serviços de planejamento familiar. (RELATÓRIO..., 1974, p. 90-93, grifo meu).

O currículo da Educação Básica também deveria ser expandido para introduzir o planejamento familiar em suas atividades.

Programas práticos e simplificados de educação devem ser desenvolvidos. Esses programas devem, onde for possivel, incluir currículos específicos que motivem a próxima geração a desejar familias de dois filhos, a fim de assegurar esse nível de fertilidade em duas ou três décadas. (RELATÓRIO..., 1974, p. 144, grifo meu).

As três décadas já se passaram. Em setembro de 2004, a população mundial apresentava 6,4 bilhões de habitantes. O Fundo de Populações das Nações Unidas (UNFPA), ao divulgar o relatório sobre a situação da população mundial em 2004, afirmou que as mulheres carecem de acesso aos meios de contracepção efetivos, principalmente nos países pobres. São mais de 200 milhões de mulheres que não sabem ou não têm como programar ou impedir sua gravidez. $\mathrm{Na}$ Conferência Internacional sobre 
População e Desenvolvimento (CIPD - Cairo, Egito/2004), 179 paises discutiram, entre outros temas, como assegurar a saúde reprodutiva e o planejamento familiar e, por conseqüência, o impedimento dos abortos e situações de risco para a mulher decorrentes deles.

Quando Carrara (1996) discorreu acerca da luta antivenérea no Brasil e no mundo, mostrou como as medidas governamentais de controle da população foram fundamentais para que o "dispositivo da sexualidade" (FOUCAULT, 1993) se estruturasse.

Através do combate às doenças venéreas, o que se buscou construir, implícita ou explicitamente, foram, simultaneamente, uma população mais permeável aos novos interesses da "bio-política" que os governos ocidentais passaram a desenvolver a partir do século $\mathrm{XIX}$, e sujeitos mais conscientes de sua responsabilidade biológica, dotados de um autocontrole que lhes permitisse resistir aos "imperativos da carne" ou colocá-los sob a segura tutela da razão. (CARRARA, 1996, p. 21, grifo do autot).

Não foi à toa que concedi, até aqui, ênfase aos discursos, projetos e ações governamentais e privados que se articularam na definição e no estabelecimento de ações e significados a uma sexualidade pautada no controle populacional, nos programas de planejamento familiar, no controle da natalidade, na definição de um modelo familiar e nas expectativas do papel da mulher nesse contexto. Talvez seja possível dizer que, no âmbito escolar, embora não explícito e materializado nos currículos escolares como uma política educacional, os primeiros anos do século XX evidenciavam "um tipo" de preocupação sexual. A Educação Sexual da época era baseada em idéias que associavam a "saúde pública" ao desenvolvimento de uma "moral sadia" e se caracterizava por uma visão higienista e médica, pelo combate explícito à masturbação e às doenças venéreas, e pelo preparo da mulher para assumir o papel de mãe e esposa. Quando, na década de 1920, feministas lideradas por Berta Lutz fizeram tentativas de implantar a Educação Sexual nas escolas, alegaram a necessidade de tal intervenção pedagógica baseada na "proteção da infância e da maternidade" (GUIMARÃES, 1995, p. 59). ${ }^{8}$

Carrara (1996, p. 241) destaca que, “[...] desde finais do século XIX [...] a Educação Sexual vinha sendo defendida pelos sifilógrafos". No Brasil, 
nas décadas de 1920-1930, no contexto do combate às doenças venéreas, sobretudo a sífilis, já havia aqueles que defendiam "[...] uma ação policial mais enérgica contra as prostitutas e a instrução e Educação Sexual da 'mocidade'[...]" (CARRARA, 1996, p. 240). Segundo o autor, medidas que poderiam ser consideradas "complementares" incluíam a obrigatoriedade da discussão no Ensino Primário, bem como o reconhecimento da organização de um "[...] programa de Educação Sexual adaptável aos diferentes estabelecimentos de ensino" (CARRARA, 1996, p. 241). ${ }^{9}$

É indiscutivel a hegemonia que as temáticas relacionadas e derivadas do "planejamento familiar" e de uma "sexualidade reprodutiva" assumiram no currículo da Educação Sexual, que se caracterizava (e ainda hoje é possível perceber) pela forte abordagem biológica e higienista. No entanto, por certo, podemos também conjeturar o quanto outros temas foram trazidos à escola. $\mathrm{O}$ século $\mathrm{XX}$ explicitou não apenas a organização de movimentos sociais por busca de conquistas políticas e civis, mas apontou para os efeitos culturais de novos significados, de novas representações acerca das sexualidades e dos gêneros trazidas por esses sujeitos e por suas identidades culturais subordinadas.

$\mathrm{Na}$ década de 1960, um conjunto de condições se arranjou, favorecendo reflexões e mudanças de todas as ordens, sejam elas políticas, sejam raciais, étnicas, de gênero e sexuais, culminando nas determinações mais recentes em favor dos direitos civis de populações subordinadas. A cassação do Congresso Nacional da África do Sul, que em 1960 instalou um dos sistemas de segregação racial mais poderosos que a humanidade já viu, consternou o mundo ocidental, conhecedor das dificuldades até então enfrentadas pelo movimento de direitos civis dos negros norte-americanos, iniciado na década de 1950 por Martin Luther King.

O lançamento da pílula anticoncepcional (em 1962, nos EUA) foi possível num contexto histórico e político favorável (mesmo com resistências de ordem moral e religiosa). A pílula não foi o evento responsável pela propalada revolução nos costumes sexuais de mulheres e de homens, mas é um incontestável símbolo paradigmático dessas mudanças que obrigaram o mundo ocidental a ressignificar as concepções vigentes acerca da reprodução, da maternidade e do casamento. Como artefato, a pílula passou a ser utilizada por campanhas de planejamento familiar e controle da natalidade, integrando o contexto 
das pedagogias para as sexualidades e os gêneros. Ela passou a ser vista como uma possibilidade de "[...] 'emancipação' sexual feminina ao 'amor livre' (preconizado desde o início das lutas feministas, no século $\mathrm{XIX)}$, possibilitando uma mulher mais independente, mais segura, com maior autonomia sobre seu corpo e seu prazer" (FURLANI, 2003, p. 77). Sem dúvida, poder impedir a contracepção era um ato que ia muito além da simples "[...] capacidade aumentada de se limitar a gravidez" [...]; "marcou uma profunda transição na vida pessoal. Para as mulheres [...] a sexualidade tornou-se maleável, sujeita a ser assumida de diversas maneiras, e uma 'propriedade' potencial do indivíduo" (GIDDENS, 1993, p. 37).

A década de 1960, comumente, é caracterizada como uma "era de liberalismos e revoltas". No entanto, na análise de Weeks (2000, p. 54), esse período "[...] parecia dividido entre um relaxamento dos velhos códigos sociais autoritátios e a descoberta de novos modos de regulação social, baseados no que havia de mais moderno na psicologia social e numa redefinição da divisão público/privado".

Lobo e Athayde (2005, p. 12), em artigo intitulado "Liberdade ou rendição", referem-se à chamada "revolução sexual" (dos anos 1960) como sendo possibilitada por "[...] uma sucessão de eventos decisivos" iniciados nos anos 1940.

O uso de antibióticos possibilitou o controle de doenças sexualmente transmissíveis, como a sífilis. Alfred Kinsey desnudou tabus ao divulgar suas pesquisas sobre o comportamento sexual dos americanos. Houve uma rápida integração das mulberes ao mercado de trabalho. A proliferação de politicas de planejamento familiar vieram em resposta à necessidade de conter o crescimento populacional. $A$ pílula permitiu a dissociação de sexo e reprodução. $\mathrm{O}$ ensino universitário expandiu-se e disseminaram-se, sobretudo entre jovens de classe média, várias utopias revolucionárias. A televisão popularizou-se e a presença das induistrias do entretenimento e da publicidade na vida cotidiana aumentou rapidamente. (LOBO; ATHAYDE, 2005, p. 10, grifos meus). 
Ao encontro dessa argumentação, Fonseca (2002, p. 269) afirma que descobertas científicas no século XX, como a pilula anticoncepcional, a fertilização in vitro, a "barriga de aluguel", os exames de DNA para paternidade duvidosa, contribuíram para o estabelecimento, hoje, de várias "estruturas familiares" no Ocidente: as "[...] rígidas convenções morais foram cedendo a valores recentes, centrados na auto-realização e satisfação emocional, as relações conjugais [...] tornaram-se abertas à negociação" (FONSECA, 2002, p. 271). Parece que este contexto, entre outros, possibilitou o surgimento da "família pós-moderna", caracterizada, hoje, pela pluralidade de conformações.

Outros fatos convergiram nesse período histórico, frutos de processos já iniciados em outras épocas e que possibilitaram condições de emergência dos discursos presentes nos diversos tipos de Educação Sexual que se instalaram no social e no escolar. Refiro-me, sobretudo, àqueles que foram marcados pela resistência e pela oposição aos sistemas de poder hegemônicos. Foucault (1993) mencionou que a resistência a modelos e discursos hegemônicos pode possibilitar o surgimento de novos discursos e promover mudanças sociais. Neste sentido, a década de 1960 foi também marcada pelos movimentos sociais por direitos humanos e pelos questionamentos sobre o colonialismo internacional como mecanismo de poder social. No contexto das lutas por direitos civis, contribuiu, para isso, a indignação mundial com os assassinatos de John F. Kennedy (em 1963) e Martin Luther King (em 1968). O assassinato de Che Guevara (em 1968) acenou para a liberdade política dos países latino-americanos e para os impasses nos processos de colonização.

Em contraste com os movimentos de denúncia das desigualdades, no Brasil ocorreu o Golpe Militar (1964), com a limitação dos direitos políticos e civis dos(as) cidadãos(ãs) brasileiros(as). Na cultura "pop", os Beatles tornaram-se sucesso em 1965, ao mesmo tempo em que a moda ousou lançar a transgressora minissaia aos costumes ocidentais. A Revolução Cultural na China (em 1966), o Movimento da Tropicália no Brasil (em 1967), a Revolução Estudantil na França (em 1968) e o Festival Woodstock (em 1969) acenaram para mudanças radicais, subvertendo modelos conservadores nas artes, na política e na cultura. Neste efervescente ambiente político mundial, destaco a agressão sofrida por gays no Stonewall Bar, em Nova York, no dia 28 de junho de 1969, fortalecendo e "iniciando" a organização política 
do movimento de gays e lésbicas na busca por seus direitos civis, sexuais e políticos. ${ }^{10}$

Louro (1999, p. 129-130), ao se referir aos anos 1960, diz que:

Para muitas pessoas esse período é considerado fundamental no âmbito das relações de gênero e sexuais, seja porque percebem ali o início de uma era de "permissividade", seja porque o identificam com a "revolução sexual", seja porque registram um incremento na "mercantilização do sexo", ou ainda porque observam grandes mudanças nas formas de "regulação da sexualidade" - com a crescente referência à homossexualidade, ao aborto, à pornografia etc.

Essas transformações e demandas sociais se refletem nos currículos escolares de todas as épocas. Guimarães (1995), quando apresenta um histórico da educação no Brasil, mostra que sempre houve inúmeras iniciativas de instituir oficialmente o ensino da Educação Sexual. Essas iniciativas estiveram presentes em todas as décadas, em especial a partir dos anos 1920, quer seja em escolas isoladas, quer seja em secretarias estaduais ou municipais de educação. As transformações culturais dos anos 1960, por exemplo, puderam ser vistas no Colégio de Aplicação da USP na discussão de específicos temas de interesse da época: prazer, métodos anticoncepcionais (pílula), gravidez, doenças venéreas, prostituição, adultério, mãe solteira, aborto, parto, amor livre. ${ }^{11}$

Naquele momento histórico dos "anos dourados", ao mesmo tempo em que havia uma abertura cultural pela música, pelos costumes, pelas roupas, pelo comportamento desprendido, a ditadura militar, no Brasil, promovia um fechamento político num clima de violência e repressão. Os trabalhos de Educação Sexual reiteravam algumas representações da sexualidade em enunciados que nos apontam as regras de inteligibilidade cultural daquela época: "[...] a masturbação era associada à imaturidade; a homossexualidade era vista como desvio sexual; o amor livre escandalizava; a libertação da mulher suscitava o questionamento irônico: como a mulher irá usar sua liberdade?” (GUIMARÃES, 1995, p. 64-65).

No contrapasso do surgimento da pilula e da contracepção, de 1966 até 1969 , a ordem política e militar instalada no Brasil incentivou a natalidade. 
Foi publicado no Diário Oficial de São Paulo, ato n.9, de 28/1/1965, de autoria de Nogueira (apud GUIMARÃES, 1995, p. 66), a seguinte nota:

É vedado aos professores do ensino de grau médio, especialmente os de biologia e sociologia, exporem na escola pública, e menos ainda, defenderem a limitação de filhos ou qualquer meio de anticoncepção. A violação desse preceito acarretará suspensão do professor, apurada a sindicância.

Mesmo diante desse quadro ditatorial e normatizador, houve iniciativas legislativas de aprovação de leis propondo a Educação Sexual obrigatória nas escolas de I e II Graus, como, em 1968, o Projeto de Lei da deputada federal Júlia Steimbruck. O Projeto foi rejeitado pelo Senado, barrado na Comissão Nacional de Moral e Civismo, pois "[...] temia-se escândalos; defendia-se a 'pureza e a inocência"' (WEREBE apud SOARES, 1985 , p. 19).

Há quem diga que, na década de 1970, a Educação Sexual no Brasil parece ter "andado pra trás" - assim como o contexto mundial foi marcado por um exagerado controle e pudor. A morte de alguns ícones internacionais da transgressão, da rebeldia e da denúncia social trouxe, novamente, à tona a discussão de questões polêmicas: Janis Joplin (em 1970) e Jimi Hendrix (em 1973) suscitaram a problemática do consumo de drogas por uma juventude cada vez mais "fora do controle"; Leila Diniz (em 1973) mostrou a possibilidade de "empoderamento" de uma "nova mulher"; e Pablo Picasso (em 1973), através de sua obra, trouxe à tona os horrores da guerra, do uso da violência, da arbitrariedade suscitando a reflexão sobre as mais diversas formas de intolerância e de opressão humana.

A consciência gay e lésbica deu seu primeiro sinal de organização e disposição para o início de uma luta histórica de conquistas dentro de sua política identitária de visibilidade: em 1970, a primeira passeata do orgulho gay e lésbico aconteceu em Nova York, e em Londres organizou-se a Frente de Libertação Gay (GLF). Em 1978, realizou-se a primeira Gay Night, na Disneylândia; no Brasil, foi fundado o jornal gay $O$ Lampião. Entretanto, o movimento de gays e lésbicas mostrou que, na emergência histórica dos discursos sobre as sexualidades e os gêneros, nem sempre as opiniões convergem positivamente: o movimento intensificou denúncias 
de homofobia e resistiu aos padrões da normalidade hegemônica. A década de 1970 marcou, ainda, no Brasil, o surgimento daquele que foi considerado o primeiro personagem gay na TV brasileira (na novela " $\mathrm{O}$ rebu", protagonizado por Ziembinski, em 1974), "inaugurando" a entrada da homossexualidade na mídia televisiva.

A aprovação da Lei do Divórcio, em 1977, também explicitou a resistência social, sobretudo, ao discurso religioso, que insistia em enunciar o casamento como indissolúvel nas "leis de Deus". Mesmo sendo aprovada num ambiente tenso e intranqüilo, a nova lei permitiu a normatização de uma situação até então legitimada pelas práticas da sociedade brasileira e pela jurisprudência existente.

Os anos 1980 encontram uma sociedade ocidental, senão mais consciente politicamente, pelo menos mais acostumada e atenta às discussões sobre cidadania, direitos humanos, democracia e diversidade cultural. A década inaugura a era do "ecologicamente correto" (termo criado nos EUA, no meio jornalístico), ofuscada com as inúmeras agressões ao meio ambiente e aos ecossistemas naturais. Em todo o mundo, surgiram organizações de defesa dos animais e do meio ambiente. O ambientalismo passou a se constituir, para muitos, na posição de sujeito central de sua identidade cultural. No final dos anos 1980, inúmeras manifestações internacionais, envolvendo dirigentes de países (entre elas, a ECO/92, realizada no Rio de Janeiro - Brasil), mostraram que "ser ecologicamente correto" passava a ser uma exigência, tanto para as pessoas como para as nações e para as organizações, e requeria a adoção de procedimentos e de medidas legais (como leis mais rígidas na industrialização e na proteção do consumidor); atenção aos produtos que destruíssem a camada de ozônio, e até condutas pessoais (como andar de bicicleta e evitar os automóveis, que poluíam o ar com monóxido de carbono; economizar luz elétrica e água; usar casacos de pêlo sintético, evitando a mortandade de animais silvestres; reciclar o lixo; não jogar alimento fora; plantar árvores e exigir dos governantes a arborização da cidade e a preservação do patrimônio arquitetônico, cultural e paisagístico).

Importantes transformações políticas marcaram os anos 1990, como as observadas no Leste Europeu, no fortalecimento dos sistemas democráticos em diversos países da América Latina e no crescimento e na visibilidade das lutas por direitos civis de diversos grupos marginalizados 
de nossa sociedade (como os movimentos de negros e negras, e de gays e lésbicas). No contexto internacional, ficaram mais evidentes as discussões sobre a situação da criança/infância, sobretudo quanto aos aspectos ligados à prostituição, à pedofilia, ao abuso sexual, à violência doméstica, ao trabalho infantil. Somadas aos movimentos sociais e políticos no Brasil, conseguiram fazer com que fosse aprovado, em 1990, o Estatuto da Criança e do Adolescente - ECA (Lei $n^{\circ} .8 .069$, de 13 de julho de 1990).

Mas voltemos ao início dos anos 1980 , que também foi marcado pelo surgimento de uma nova doença. A história da AIDS estava sendo iniciada, e seu primeiro capítulo era, precipitadamente, denominado de "o mistério homossexual". Os médicos estadunidenses, em 1982, referiamse a ela por Gay Relationad ImmunoDeficiency - GRID, o que não apenas estigmatizava a população masculina homossexual, mas "embaraçava" o raciocínio daqueles(as) que pretendiam investigar e conhecer a doença. Ao ser qualificada como causadora de um complexo de sintomas, sua condição de "síndrome" passou a ser palavra determinante na nova nomenclatura: surge a AIDS-gay (Acquired ImmunoDeficiency Syndrome) -, mas, mantendo, ainda, o atrelamento restrito com a homossexualidade. No entanto, durante os meses de julho e agosto de 1982, as idéias da AIDS-gay (relacionada à homossexualidade masculina) desmoronaram bruscamente:

Foram, com efeito, detectados casos entre mulheres, depois entre crianfas bemofilicas, entre bomens viciados $\mathrm{em}$ heroína e, sobretudo, o que em síntese constituía um "mistério", num lactente que recebera transfusão ao nascer, e num beterossexual comprovado, submetido à transfusão no Haiti. (LEIBOWITCH, 1984, p. 23, grifo meu).

A associação restrita da homossexualidade com a AIDS estava sendo perturbada. As transfusões de sangue (e seus derivados) passavam a ser tão protagonistas da doença quanto as relações sexuais. Na nomenclatura médica e midiática, a expressão AIDS-gay "deixava de existir", passando a ser apenas AIDS. Essas denominações "oficiais" da AIDS, durante o ano de 1982, contribuiram para acentuar a falsa relação restrita da doença com a homossexualidade (sobretudo a masculina); entretanto, inúmeros outros termos (de cunho pejorativo, irônico e negativo) estiveram presentes nos enunciados, nos mais diversos meios sociais e contextos, durante 
toda a década de 1980. Por exemplo, igrejas conservadoras, num claro posicionamento preconceituoso (e oportunista) sobre a homossexualidade, divulgaram representações da AIDS como "um castigo divino". Outros enunciados também surgiram, referindo-se à doença como "[...] 'câncer gay', 'peste gay', 'peste rosa"' (SANTOS, 2002, p. 18). Essa construção histórica na nomenclatura da doença, associando-a às práticas homossexuais, foi sem dúvida um forte fator de aumento da homofobia social (do preconceito, da intolerância e da violência), mas também proporcionou uma maior visibilidade dos sujeitos gays e lésbicas, e dos relacionamentos entre pessoas do mesmo sexo.

Destaco que foi o discurso médico da AIDS (adotado por muitas instituições) que, inicialmente, favoreceu o preconceito e a discriminação contra os homossexuais, sendo disseminado e assumido em muitas representações educacionais. Embora no Brasil a representação preconceituosa tenha sido mais intensa em relação aos homossexuais homens, Gambá Júnior (2002) menciona que "[...] a doença seguiu um trajeto de segregação social". Nos EUA, "extra-oficialmente", ela foi associada a outras "minorias" (melhor dizer, a outras posições de sujeito), sendo popularmente chamada de a doença dos "agás" (Hs) ou seja, dos Homosexuals (homossexuais), Hemophilic (hemofilicos), Heroinomans (heroinômanos - consumidores de heroína), Haitians (Haitianos) e Hookers (prostitutas).

No entanto, muitos setores da sociedade, num processo de repensar (e ressignificar) a AIDS, começaram a transferir o entendimento de "grupos de risco" para "grupos com comportamento de risco", obrigando a uma mudança pedagógica nas representações das identidades sexuais, das práticas sexuais e do sexo seguro, com repercussão evidente no currículo da Educação Sexual.

Para Trevisan (2000, p. 462),

[...] o vírus da Aids realizou em alguns anos uma proeza que nem o mais bem-intencionado movimento pelos direitos homossexuais teria conseguido, em muitas décadas: deixar evidente à sociedade que o homossexual existe e não é o outro, no sentido de um continente à parte, mas está muito próximo de qualquer cidadão comum, talvez ao meu lado e - 
isto é importante! - dentro de cada um de nós, pelo menos enquanto virtualidade.

A AIDS não apenas possibilitou uma maior visibilidade dos sujeitos homossexuais e lésbicos, sobretudo se pensarmos na importância disso nas políticas de identidade e nos processos de produção de saberes sobre os gêneros e sobre as sexualidades. Ela também possibilitou, segundo Trevisan (2000, p. 463), um “[...] extraordinário efeito colateral dessa epidemia sexualizada [...] [e trouxe] elementos inestimáveis para educação da sexualidade [...] Deflagrou-se uma epidemia de informação [...] e nunca se discutiu tanto a realidade homossexual como nos tempos de Aids".

Weeks (2000) argumenta que, entre os anos 1960 e 1980, surgiu um "novo moralismo", que passou a conceder suma importância aos temas da sexualidade e do gênero, elaborando uma política sexual para o Ocidente. Essa política, oriunda de uma "direita moral", se organizou para combater os aparentes avanços conquistados (na visibilidade social e nas mudanças jurídicas), sobretudo, pelos movimentos de gays, de lésbicas e de feministas, passando a disputar espaço pela Educação Sexual nas políticas públicas de saúde e de educação (nos projetos e nos currículos escolares). Talvez esses movimentos organizados conservadores possam ser mais facilmente reconhecidos em abordagens da Educação Sexual do tipo moral tradicionalista, do tipo terapêutico ou do tipo religioso radical. ${ }^{12}$

A partir dos anos 1980, mais enfaticamente nos campos acadêmico e dos movimentos sociais, os estudos de gênero e os estudos sobre mulheres apontaram para os construídos mecanismos de representação e de subordinação feminina na cultura e na sociedade. O movimento feminista, ao explicitar os meandros das relações de poder no cerne dos processos educativos que constituem os sujeitos, contribuiu para mudanças nas instituições públicas sociais.

No contexto das mudanças sociais, as mulheres, cada vez mais e gradativamente, começavam a exercer funções antes consideradas apenas para os homens. ${ }^{13} \mathrm{~A}$ efervescência democrática da Campanha das "Diretas Já", em 1984, criou campo favorável às mudanças sociais às mulheres, esperadas com a nova Constituição Federal, promulgada em 1988. O Conselho Nacional dos Direitos da Mulher, criado em 1985, durante a Constituinte, vivia sua primeira gestão (1985-1989) e empenhou-se em 
campos como saúde, violência, criação de creches, educação, legislação, trabalho. Criou a campanha "Constituinte para valer tem que ter palavra de mulher" (FARAH, 2004, p. 51), que ficou conhecida no Congresso Nacional como o "lobby do batom". Essa mobilização representou parte dos anseios da mulher cidadã em 28 dispositivos inovadores, entre eles, o art. $3^{\circ}$ - "principio da igualdade - origem, raça, sexo, cor e idade"; e o art. $5^{\circ}-$ "Homens e mulheres são iguais em direitos e obrigações". Questões que envolviam os direitos políticos e civis das mulheres trouxeram à tona a violência doméstica, a exploração salarial, as desigualdades e a hierarquia social a que essas estavam submetidas culturalmente. ${ }^{14}$

Os estudos feministas elaboraram a categoria "gênero" e passaram a demonstrar sua produtividade para análise sociocultural e política. Nesses novos tempos, as mulheres passavam a conquistar, politicamente, espaços mais efetivos. Talvez possamos pensar em alguns acontecimentos indicativos dessa nova condição de possibilidade: um deles foi quando, em 1989, Marilia Gabriela tornou-se a primeira mulher a mediar os debates na TV entre candidatos à Presidência da República do Brasil. "As mulheres", publicamente, pareciam se "revestir" de um poder até então sem precedentes na mídia brasileira. Em 1994, quando o Itamaraty fazia os preparativos para a participação brasileira na Conferência Internacional da Mulher, em Pequim, a comitiva brasileira incluiu a discussão do texto "Relações de gênero e poder", de Fanny Tabak.

O movimento gay e lésbico internacional começou a vencer suas primeiras batalhas jurídicas em países europeus: em 1984, a Hungria tornou-se o primeiro país do mundo a considerar legais as relações sexuais entre pessoas do mesmo sexo; em 1985, o parlamento dinamarquês aprovou a igualdade sobre a taxa de herança entre duas pessoas do mesmo sexo; e, em 1989, a Dinamarca legalizou a parceria civil registrada entre pessoas do mesmo sexo.

No Brasil, Cecil Thiré viveu um papel gay na novela "Roda de fogo" - Globo (em 1987), e surgiu publicamente o "primeiro" transexual do país, Roberta Close (em 1989). Com a morte, por AIDS, do ator Rock Hudson (em 1985), o mundo pareceu acordar para os rigores da dissimulação sexual imposta pela heteronormatividade na cultura em geral e, neste caso, exemplarmente demonstrado no mundo do cinema. Iniciaram-se os movimentos mundiais que estimulavam a "saída do armário" e o "outing" cinematográfico e político como estratégia de visibilidade gay e lésbica. 
Na década de 1990, estavam ainda mais fortalecidos os movimentos gays e lésbicos mundiais. Após a morte de Cazuza (em 1990), Renato Russo revelou que era gay, e a juventude brasileira viu-se diante de um quadro que considero educativamente fascinante e contraditório: constatar e admitir a sexualidade gay de um ídolo e lidar com a conservadora e, muitas vezes, violenta atitude adolescente de homofobia. Sem dúvida, um contexto paradoxal, na medida em que explicitou a intensa e inquestionável identificação adolescente com um ícone musical que personifica, por meio de suas letras de protesto, o amor entre iguais (negado homofobicamente por essa mesma juventude). Renato Russo morreu em 1996 - no ano em que as experiências científicas confirmaram a eficácia dos coquetéis contra a AIDS.

Comentei, anteriormente, neste artigo como, no século $\mathrm{XX}$, o surgimento da pilula anticoncepcional e das novas tecnologias reprodutivas provocou impactos na representação hegemônica de familia. Hoje, no entendimento plural acerca das famílias contemporâneas, destacam-se também aquelas constituídas entre pessoas do mesmo sexo, favorecidas principalmente pelo contexto emergente de visibilidade, nacional e mundial, da homossexualidade, nos últimos anos. Fonseca (2002, p. 272) problematiza a questão quando afirma que "[...] parceiros do mesmo sexo ganharam um espaço importante"; e provocativamente a autora pergunta: "[...] se a afeição é a verdadeira base do relacionamento, por que o casal seria limitado a um relacionamento heterossexual centrado em torno da reprodução biológica?".

Sem dúvida, o contexto mundial dos anos 1990 prestou atenção, mais atentamente, ao discurso jurídico que concedia ênfase ao argumento da "isonomia da lei" a todas as pessoas. Celebrou-se a "diferença", e, em especial no mundo europeu, os parlamentos começaram a alterar leis e a reconhecer a cidadania gay e lésbica: em 1993, a França concedeu o benefício do seguro social a parceiros(as) do mesmo sexo, e a Noruega legalizou a união civil entre pessoas do mesmo sexo. Até esse ano, a Rússia considerava crime, com pena de até cinco anos, a prática homossexual entre homens; a partir de 1993, a lei foi reformulada, tornando legal a relação sexual consentida entre homossexuais masculinos a partir dos 18 anos. Em 1994, na Holanda, o governo apresentou uma lei dando aos casais homossexuais direitos semelhantes aos dos heterossexuais. A Inglaterra reduziu de 18 
para 16 anos a idade legal mínima para relacionamentos entre mulheres e homens, e de 21 para 18 anos, a idade legal mínima para relacionamentos entre gays e lésbicas.

Através da mídia, o mundo tomou conhecimento das desigualdades e da violência a que as mulheres estão submetidas, sobretudo por meio de relatos de culturas não ocidentais, sob forte influência de religiões fundamentalistas. A Educação Sexual, no final dos anos 1990, integrou esse contexto, explicitando discussões que envolviam relações de gênero, alteridade, violência doméstica e sexual, fanatismo religioso, multiplicidade cultural, ética e direitos humanos. As relações de gênero perpassam, indiscutivelmente, os processos de violência experimentados por mulheres em todo o mundo.

Neste contexto de análise e crítica cultural, vale uma ponderação: mesmo que minhas observações sejam passíveis de crítica, sobretudo por eu estar apresentando o ponto de vista de um possível "olhar estrangeiro" (que julga culturas e valores distintos dos seus próprios), aponto para alguns acontecimentos dos anos 1990 que tiveram grande repercussão na mídia brasileira: em 1990, na China, mais de 50 mil seqüestros de garotas adolescentes foram registrados, em especial, em regiões onde não havia mulheres adultas; as adolescentes eram vendidas a preços que variavam de 150 a 600 dólares; na maioria das vezes, eram estupradas pelos traficantes. Em 1992, em Bangladesh, uma garota de 14 anos e sua mãe foram condenadas a chibatadas em público; o crime: a garota tinha sido estuprada por um habitante do vilarejo, mas não havia quatro "bons muçulmanos" testemunhando o crime; o estuprador foi solto por falta de provas, segundo a Lei Islâmica; em conseqüência da gravidez resultante do estupro, a adolescente foi condenada pelo código de Zina, por sexo fora do casamento. Em 1993, Noorjahan Begum foi enterrada até a cabeça e apedrejada até a morte, depois que um sacerdote decidiu que o divórcio e o novo casamento dela haviam ferido as leis islâmicas. Em 1995, no Egito, foram criadas duas leis: a Lei da Obediência (que passou a obrigar a mulher a se submeter totalmente à autoridade do marido) e a Lei do Retorno (que passou a conferir poderes à polícia para trazer a mulher de volta para casa, à força, mesmo que tenha fugido para se proteger de violência doméstica). No Iraque, nesse mesmo ano, Saddan Hussein anunciou, em cadeia de TV, a permissão legal aos homens (qualquer homem) para matar qualquer 
mulher suspeita de "má conduta" (entenda-se: adultério), independente de ele ter com ela grau de parentesco ou não.

Em 1994, a Organização Mundial da Saúde (OMS) divulgou que duas mulheres para cada homem sofriam de ansiedade, depressão e estresse, decorrentes do seu papel socioeconômico desigual. Nesse mesmo ano, no Brasil, foram reveladas a escravização sexual e a prostituição de garotas adolescentes (nos garimpos da Amazônia), e a indústria do sexoturismo ou pornoturismo (em Recife e Fortaleza).

\section{O que esses fatos históricos dizem aos cursos de formação de educadoras(res)?}

Esse conjunto de fatos, obviamente, não pretende ser conclusivo ou suficiente para a compreensão das políticas de identidades, sexuais e de gêneros, tampouco para a definição de políticas curriculares voltadas à Educação Sexual, qualquer que seja o nivel de ensino. Minha intenção foi apontar alguns eventos, sobretudo aqueles que podem ser considerados relevantes à constituição dos significados referentes aos gêneros $e$ às sexualidades, a partir da segunda metade do século XX e início do Terceiro Milênio, e situar melhor o contexto das discussões curriculares. Esses acontecimentos tornaram visiveis novos sujeitos e também práticas sexuais plurais (as não dominantes). Eles podem ser vistos e compreendidos como efeitos e como parte integrante constitutiva de distintas políticas para as sexualidades, para os gêneros e para seus sujeitos.

Ao se referir à multiplicidade e à complexidade dos fatos e das coisas ditas no meio social, e ao se referir à importância da análise foucaultiana nas pesquisas educacionais, Fischer (2003, p. 377) argumenta que "[...] expor essas multiplicidades nos permitirá descrever um pouco os regimes de verdade de certa formação histórica e de determinados campos de saber".

Parece que esses movimentos de contestação e de resistência, além de terem contribuido (e contribuem) para o surgimento de novas identidades sociais (aquelas que se encontravam não autorizadas, reprimidas, escondidas, ocultas), permitem, também - em torno dessas identidades e a partir das temáticas que suscitam hoje - o estabelecimento de redes de solidariedade e de organização social, política e acadêmica (como grupos organizados, 
ONGs, núcleos de estudos em universidades, grupos de pesquisa, etc.) com significativos reflexos nas instituições públicas e na Educação.

Este processo de visibilidade não só questiona/questionou, mas desestabiliza/desestabilizou a identidade hegemônica, tida como universal e até então inquestionável - aquela centrada no indivíduo moderno que é homem, heterossexual, branco, masculino, ocidental, adulto, cristão, de classe média. A visibilidade de novas formas de saber (política, cultural, estética, afetiva) certamente cria, criou e criará ambientes favoráveis e indispensáveis na escola aos trabalhos de Educação Sexual, suscitando temáticas... Suscitando impasses... Suscitando reflexões...

[...] práticas produzidas por múltiplos saberes de uma determinada época [...] interpelam sujeitos, produzem felicidades e dores, rejeições e acolhimentos, solidariedades e injustiças, e igualmente políticas públicas de saúde, de educação, de emprego, e assim por diante. (FISCHER, 2003, p. 379).

$\mathrm{Na}$ escola (mas não apenas nela), as identidades sexuais e de gênero estão sendo constantemente produzidas. As instituições públicas e as mais diversas mídias também estão impregnadas (e são produtoras) de representações acerca das sexualidades e dos gêneros. A escola lida, o tempo todo, tanto com facetas mais conservadoras e moralistas da sociedade quanto com as suas vanguardas transgressoras.

Para Epstein e Johnson (2000, p. 26), “[...] no geral, os debates públicos sobre a sexualidade estabelecem os parâmetros do que é possível ou permissível nas escolas". Mesmo que existam diversas formas de conceber, organizar, planejar e "fazer" a Educação Sexual, os efeitos desta educação estarão diretamente ligados aos conhecimentos que são veiculados e ao comprometimento político (ou não) com os mecanismos de poder social que instauram as desigualdades.

Britzman (2000, p. 102) fala em um "modelo preventivo de Educação Sexual" a partir do comentário sobre o livro Culturas sexuais e culturas de adolescentes. Interessavam à autora os artigos que "[...] discutem os efeitos sociais - de exclusão e normalização em termos de uma Educação Sexual que tem como norma a sexualidade branca, de classe média e heterossexual" (BRITZMAN, 2000, p. 102). Para ela, numa "Educação Sexual preventiva", 
os saberes estariam organizados em três frentes: a prevenção de dano corporal (DSTs e gravidez precoce); a prevenção e a proteção contra homofobia, racismo e ceticismo; a prevenção de estereótipos de gênero e incapacidades fisicas.

No olhar sobre a história, o importante é perceber que existe uma relação direta entre a forma como certa identidade e certo sujeito são representados e o movimento cultural, social e político da construção dos saberes de sua(s) representação(ões). Todo saber é construção. A constatação dos saberes hegemônicos e/ou da existência de desigualdades sociais não justifica a paralisia educacional, pois é o discurso que inventa, que constrói as representações acerca dos gêneros e das sexualidades, que regula, que exclui, que normatiza... Mas, sem dúvida, é o discurso que também reinventa, desregula, inclui, pluraliza.

Diante do universo de identidades sexuais e de gênero que ficam à margem da norma (limitada, mas hegemônica que privilegia a heterossexualidade), Britzman (2000) fala da "Educação Sexual socialmente relevante", ou seja, a que considera que todas as identidades são construídas e significadas, na história, por relações desiguais de poder. "Os esforços pedagógicos poderiam, então, deixar de utilizar o saber para controlar identidades específicas [...]. [Seu] currículo consistiria em incitar identificações e críticas" (BRITZMAN, 2000, p. 106), oferecendo novas e outras questões, e não as fechando.

Parece-me que uma atitude nesse tipo de educação seria a problematização das formas culturais que constroem e instalam o sexismo, a misoginia, o racismo, a homofobia. A autora caminha no sentido de questionar os saberes hegemônicos que instauram as "verdades" numa cultura hegemônica:

Mas devemos também começar a admitir que essas suposições devem ser forçadas a questionar a afirmação de que existe uma forma cultural apropriada, de que existe uma idade apropriada e, na verdade, a própria idéia de relevância cultural, pois são esses os construtos que proíbem o pensamento de que a sexualidade é movimento e de que os corpos viajam (BRITZMAN, 2000, p. 107). 
Essa "Educação Sexual socialmente relevante" de que Britzman (2000, p. 107) fala necessariamente é, pedagogicamente, uma recusa “[...] aos fundamentos do eugenismo e da higiene social". A inclusão no currículo das discussões acerca do caráter histórico da sexualidade, para a autora, pode ser vista como um "[...] projeto ético de incitação ao cuidado de si" (BRITZMAN, 2000, p. 108).

Algo similar é visto quando Parker (2000, p. 139), ao se referir à pesquisa contemporânea sobre sexualidade, afirma ser importante reconhecer e considerar as contribuições do conhecimento produzido no interior de quatro movimentos sociais: "[...] a revolução sexual, o feminismo, a liberação gay e o movimento de direitos civis", que confeririam, segundo o autor, à atividade investigativa "uma perspectiva mais politizada."

[...] o ativismo gay iniciou um questionamento mais amplo dos pressupostos heterossexistas da lei, da ciência, da psicologia e das teorias de parentesco. Combinado com o feminismo, esse movimento gerou formas alternativas de perceber e incorporar a sexualidade, bem como a coesão e o desejo políticos necessários para alterar as normas e os valores ocidentais sobre a sexualidade. O movimento negro de reivindicação de direitos civis aumentou a consciência de que as ideologias da sexualidade estão carregadas de pressupostos sobre raça, classe e nacionalidade. (PARKER, 2000, p. 140, grifos meus).

Este parece ser um argumento sobre um provável caráter de mudança social que pode adquirir uma Educação Sexual. Eu diria, ainda (e por que não?), um provável caráter educacional, pedagógico e político.

\section{Uma reflexão final}

Os múltiplos discursos apresentados neste artigo são sugestivos de uma contingência histórica nas discussões sobre Educação Sexual. Eles podem ser vistos como uma demonstração da capacidade social de responder a demandas de grupos sociais contemporâneos, numa dinâmica que (re)constrói as identidades culturais e as diferenças, (re)posicionando os sujeitos. 
Apostei neste entendimento, e parece que sua pertinência tem se mostrado oportuna, quando temáticas "incomuns" à Educação Sexual (como homossexualidade, abuso sexual, adoção, estupro, separação, divórcio, diferentes organizações familiares, pornografia, erotismo infantil) têm, cada vez mais, estado presentes no âmbito da escola. Parece que os currículos escolares, lentamente, ecoam alguns temas oriundos dos movimentos sociais de meados do século XX e trazem para a escola o que talvez pudéssemos denominar de "uma nova ética sexual", "uma nova ética escolar": uma Educação Sexual que considere, sem receios, fundamental ressaltar o caráter contingencial dos processos de construção/invenção desses saberes, num movimento histórico que é político, é cultural e é pedagógico de descontinuidades e rupturas.

Nessa abordagem ética, a diversidade sexual, os direitos humanos e os direitos sexuais (e, mais recentemente, a abordagem queer) têm se apresentado como aspectos culturais e políticos imprescindíveis na problematização dos gêneros, das sexualidades e das relações étnico-raciais numa perspectiva de respeito às diferenças.

\section{Notas}

1. Texto integrante de minha tese de doutorado (FURLANI, 2005a), orientada pela Profa. Dra. Guacira Lopes Louro. Este artigo teve como orientações de composição e escrita as normas da ABNT (NBR 1472, 2002; NBR 10520, 2002; NBR 6023, 2002) e as recomendações da revista Perspectiva. Entretanto, assumo um "modo feminista de escrever", ou seja: 1) oponho-me a qualquer linguagem sexista que tenha a forma masculina como regra geral. Explicito o masculino e o feminino, ora com linguagem inclusiva (ex.: meninos e meninas), ora, quando possível, utilizando termos neutros em gênero (por exemplo: criança). Não utilizarei "homem" para me referir à humanidade; 2) escrevo na primeira pessoa. Assumo, portanto, uma postura contrária à suposta "neutralidade da ciência moderna", uma vez que os Estudos Feministas - e suas (seus) estudiosas (os) são assumidamente interessadas(os) numa sociedade menos desigual em gênero; 3) nas citações bibliográficas, torno visível a autoria citando o prenome e o sobrenome da(o) autora(or) quando da sua primeira aparição no texto. 
2. Embora o PCN se refita ao trabalho pedagógico escolar de discussão da sexualidade utilizando a expressão "orientação sexual", neste artigo utilizarei a expressão "Educação Sexual".

3. Assumo, neste artigo e em minha vida acadêmica, o referencial teórico baseado nas contribuições advindas dos Estudos Feministas e dos Estudos Culturais, sob a perspectiva pós-estruturalista de análise.

4. Ver Reis e Ribeiro (2002), que analisam, amplamente, as características educacionais propostas nos Parâmetros Curriculares Nacionais (PCNs), para discussão da sexualidade a partir do Tema Transversal "orientação sexual" e para formação de educadores(as) sexuais.

5. No início dos anos 1970, nos EUA, produziu-se um documento confidencial sob o código NSSM 200, que foi desclassificado pela Casa Branca em 1989. Este documento expressou a preocupação com o crescimento da população mundial, propondo medidas de controle; utilizou como eufemismo o nome "Serviços de Planejamento Familiar" e recomendou o uso de anticoncepcionais orais, DIUs, melhores métodos de prever a ovulação, esterilização de homens e mulheres, anticoncepcionais inevitáveis, meios leuteolíticos e autoprogesterona, e métodos não clínicos (espumas, cremes e preservativos).

6. Informação obtida no folder 'Benfam 1965-2000. 35 anos - uma parceria de sucesso".

7. Em 1996, por exemplo, o Instituto Nacional do Câncer divulgou que, no Brasil, o câncer de próstata era o segundo tipo fatal entre os homens, perdendo apenas para o câncer de pulmão. Os dados estatísticos apontavam uma ocorrência de 15 a $20 \%$ nos homens acima dos 50 anos, e $90 \%$ dos homens acima dos 80 anos. Além dessa realidade social, a notícia apontava, também, para as representações culturais acerca dos significados preconceituosos que envolviam o exame clínico preventivo (o toque retal) e acenavam para o necessário investimento numa educação sexual voltada aos homens; em 1998, o Viagra (citrato de sildenafil) foi aprovado nos EUA e autorizado, no Brasil, pelo Ministério da Saúde para o uso em tratamento com pacientes com disfunção erétil; no ano seguinte (1999), o mesmo ministério lançou a Portaria 048/99, que regulariza as esterilizações cirúrgicas (vasectomia e laqueadura) nos hospitais da rede pública do País. 
8. Os primeiros livros destinados à Educação Sexual, no Brasil, ressaltavam uma ótica médico-higienista: em 1938, o livro de Oswaldo Brandão Silva (Iniciafão sexual-educacional), que trazia em sua capa o alerta "leitura reservada", era destinado apenas para os garotos, pois as meninas deixariam de ser inocentes se o lessem (GUIMARÃES, 1995, p. 59-60). Outras obras podem ser citadas: o livro de Ogino Knauss (Métodos de controle da fertilidade); do padre Negromonte (Educaf̧ão sexual-para pais e professores, 1946); de Fritz Kahn (Nossa vida sexual, 1951) e os livros do padre Charboneau.

9. Carrara (1996, p. 242) mencionará, ainda, que, em 1928, Oscar Penna Fontenelle apresentou um projeto de lei à Câmara dos Deputados instituindo a Educação Sexual obrigatória nas escolas públicas e nos quartéis. Mesmo com manifestações favoráveis, sobretudo da instituição médica, o projeto não foi aprovado.

10. O dia 28 de junho passou a ser comemorado, mundialmente, como o Dia do Orgulho Gay (The Gay Pride) - estratégia de visibilidade e de auto-estima do Movimento. Segundo Furlani (2005b, p. 229), no movimento homossexual há disputas por representação e visibilidade entre os gêneros, o que levou várias organizações lésbicas no Brasil a criarem, a partir de 2003, o Dia do Orgulho e da Visibilidade Lésbica (19 de agosto).

11. Guimarães (1995, p. 63-64) baseia tal afirmação a partir da análise de depoimentos de monitoras de Educação Sexual da época.

12. $\mathrm{Na}$ tese de doutorado de onde este artigo se origina, descrevo essas abordagens no Capítulo 6 - Cenários da Educação Sexual.

13. Por exemplo, a Marinha Brasileira, em 1980, foi a primeira a aceitar mulheres no serviço militar; em 1982, a Aeronáutica; e, em 1989, o Exército. Em 1996, o Brasil regulamentou o serviço militar feminino voluntário, e em 1998, o Exército brasileiro passou a aceitar mulheres para treinamento em combate.

14. As delegacias da mulher foram criadas em 1985, no Estado de São Paulo, no governo de Franco Montoro. 


\section{Referências}

BRITZMANN, Deborah. Curiosidade, sexualidade e currículo. In: LOURO, Guacira Lopes (Org.). O corpo educado: pedagogias da sexualidade. Belo Horizonte: Autêntica, 2000. p. 85-111.

CARRARA, Sérgio. Tributo a Vênus a luta contra a sífilis no Brasil, da passagem do século aos anos 40. Rio de Janeiro: FIOCRUZ, 1996.

CARVALHO, Alexandre Magno Teixeira de. O processo de produção discursiva: uma visão da contribuição de Michel Foucault ao debate epistemológico. Estudos e Pesquisas em Psicologia, Rio de Janeiro: UERJ, v.1, n.1, p. $119-140,2001$.

EPSTEIN, Debbie; JOHNSON, Richard. Sexualidades e institución escolar. Madrid: Morata, 2000.

FARAH, Marta Ferreira Santos. Gênero e políticas públicas. Revista Estudos Feministas, Florianópolis, v.12, n.1, p. 47-71, 2004.

FISCHER, Rosa Maria Bueno. Foucault revoluciona a pesquisa em Educação? Perspectiva, Florianópolis, v. 21, n. 2, p. 371-389, jul./dez. 2003.

FONSECA, Cláudia. A vingança de Capitu: DNA, escolha e destino na família brasileira contemporânea. In: BRUSCHINI, Cristina; UNBEHAUM, Sandra G. (Org.). Gênero, democracia e sociedade brasileira. São Paulo: FCC/Editora 34, 2002.

FOUCAULT, Michel. Historia da sexualidade: a vontade de saber. 11. ed. Rio de Janeiro: Graal, 1993. v.1. 2000. . Arqueologia do saber. 6. ed. Rio de Janeiro: Forense Universitária,

FURLANI, Jimena. Mitos e tabus da sexualidade bumana: subsídios ao trabatho em Educação Sexual. 2. ed. Belo Horizonte: Autêntica, 2003.

O bicho vai pegar! Um olhar pós-estruturalista à Educação Sexual a partir de livros paradidáticos infantis. 2005a. Tese (Doutorado em Educação) -Universidade Federal do Rio Grande do Sul, Porto Alegre.

- Gêneros e sexualidades: políticas identitárias na Educação Sexual. In: GROSSI, Miriam Pillar et al. (Org.). Movimentos sociais, educajão e 
sexualidade. Rio de Janeiro: Garamond, 2005b. p. 219-238. (Coleção Sexualidade, Gênero e Sociedade).

GAMBÁ JÚNIOR. A maturidade da AIDS no Brasil. Mood, [Porto Alegre, 2002]. Disponível em <http://www.mood.com.br/arquivo/aids. htm>. Acesso em: 21 ago. 2002.

GIDDENS, Anthony. A transformaşão da intimidade: sexualidade, amor e erotismo nas sociedades modernas. São Paulo: Editora da UNESP, 1993.

GUIMARÃES, Isaura. Educação Sexual na escola: mito e realidade. Campinas: Mercado das Letras, 1995.

LEIBOWITCH, J. Um virus estranbo de origem desconbecida: AIDS. Rio de Janeiro: Record, 1984.

LOBO, Flávio; ATHAYDE, Phydia de. Liberdade ou rendição? Carta $\mathrm{Ca}$ pital, São Paulo, ano 11, n. 340, p. 10-14, maio de 2005.

LOURO, Guacira Lopes. Gênero, sexualidade e educação: uma perspectiva pós-estruturalista. 3. ed. Petrópolis: Vozes, 1999.

PARKER, Richard. Cultura, Economia política e construção social da sexualidade. In: LOURO, Guacira (Org.). O corpo educado: pedagogias da sexualidade. Belo Horizonte: Autêntica, 2000. p. 127-150.

REIS, Giselle Volpato dos; RUBEIRO, Paulo Rennes Marçal. A orientação sexual na escola e os parâmetros curriculares nacionais. In: RIBEIRO, P. R. M. (Org.). Sexwalidade e Educação Sexual: apontamentos para uma reflexão. Araraquara/SP: FCL/Laboratório Editorial; São Paulo: Cultura Acadêmica, 2002. p. 81-96.

RELATÓRIO Kissinger: NSSM 200. Brasília: Pró-Vida e Pró-Família, 1974. Disponivel em: < http://www.providafamilia.org/relatório_kissinger.htm>. Acesso em: 15 set. 2002.

RENATO, Paulo. Educação Sexual: programa frente a frente Rede Vida. Entrevistador: Arnaldo Niskier. Brasília: Pró-Vida e Pró-Familia,1996. Entrevista com o Ministro da Educação: Paulo Renato em novembro de 1996. Disponível em: <http://providafamilia.org/educacao.htm>. Acesso em: 21 ago. 2002.

SANTOS, Luis Henrique Sacchi dos. Biopolitica de HIV/AIDS no Brasil: uma análise dos anúncios televisivos das campanhas oficiais de preven- 
ção (1986-2000). 2002. Tese (Doutorado em Educação) - Universidade Federal do Rio Grande do Sul, Porto Alegre.

SILVA, Tomaz Tadeu da. Teoria cultural e educacão: um vocabulário crítico. Belo Horizonte: Autêntica, 2000.

SOARES, Maria da Graça. Educaf̧ão Sexual na escola: percepção de pais, alunos e educadores; sugestão de programa. 1985. Dissertação (Mestrado em Educação) -Pontifícia Universidade Católica do Rio Grande do Sul, Porto Alegre.

TREVISAN, João Silvério. Devassos no paraíso: a homossexualidade no Brasil, da Colônia à atualidade. Rio de Janeiro: Record, 2000.

WEEKS, Jeffrey. O corpo e a sexualidade. In: LOURO, Guacira Lopes (Org.). O corpo educado: pedagogias da sexualidade. Belo Horizonte: Autêntica, 2000. p. 37-82. 
Sexual Education:when the articulation of multiple discourses allows its inclusion in the curriculum

\section{Abstract:}

Is it possible to find space for sexual education in the Brazilian educational curriculum today? To what degree has contemporary society created demands that favor the inclusion of issues related to sexuality, gender and identity policies? What does this historical context and requirement have to say for teacher education courses? This article maintains that the last half of the 20th century was a determining period in the discussion and inclusion of Sexual Education in social and educational realms in Brazil. According to Michel Foucault, multiple discourses participate in the construction of social knowledge about sexualities and genders. These discourses are articulated by "historic discontinuities" in the processes that define representations about the subjects and their cultural identities. I present a historical mapping of the demands of a political, cultural, media, pedagogic, aesthetic and economic order that appear to indicate the thematic and didactic-methodological possibilities that a Sexual Education curriculum can assume today at any educational level.

Key words: Sexual Education. Teacher Education.
Educación Sexual: cuando la articulación de múltiples discursos posibilita la inclusión curricular

\section{Resumen:}

Es posible hoy, en la escolaridad brasilera encontrar espacio en el currículo para la educación sexual? En qué medida la sociedad contemporánea crío (y cría) demandas que favorecen la inclusión de temáticas como la sexualidad, el género, las políticas de identidad? Que, este contexto histórico y esta demanda tienen para decir a los cursos de formación de educadores (as)? Defiendo el presupuesto de que la última mitad del siglo $\mathrm{XX}$ fue determinante en la discusión y en la inclusión de la educación sexual en los ámbitos social y educacional en Brasil. Según Michel Foucault, múltiples discursos participaron en la construcción de saberes sociales en relación a las sexualidades e los géneros. Eses discursos se articulan por "discontinuidades históricas" en los procesos que definen las representaciones acerca de los sujetos y sus identidades. Presento un panorama de las demandas de orden política, cultural, mediática, pedagógica, estética y económica que parecen apuntar en dirección a las posibilidades temáticas y didáctica - metodológicas que un currículo de Educación Sexual puede asumir en los días de hoy, en cualquier nivel de la enseñanza.

Palabras-clave: Educación Sexual. Educadores-Formación. 


\section{Jimena Furlani}

Universidade do Estado de Santa Catarina (UDESC)

Centro de Ciências Humanas e da Educação (FAED)

Servidão Revoar das Perdizes, 106 - Campeche

Florianópolis, SC - 88063-077

Fones: (48) 32379127 / (48) 91014321

E-mail: jimena@udesc.br

www.udesc.br/multiulturalismo/educacaosexual

Recebido em: $13 / 3 / 2006$

Aprovado em: 7/5/2006 